\title{
ENTRE CLASICISMO Y VANGUARDIA: EL COMPROMISO POÉTICO EN LOS AUTORES DE LOS AÑOS OCHENTA
}

Luis BAGUÉ QuíLEZ Universidad de Alicante

\section{Algunas notas sobre el panorama poético de los años ochenta}

En los versos finales del poema «Asturcón», edificado sobre el epigrama homónimo de Marcial, Víctor Botas defendía una poesía despojada de «rituales ínfulas» e «insensatas guirnaldas», y proponía adornar su lirismo tan sólo con «unas gotas / de sonriente coña beatífica» (Botas, 1999: 294-295). Ya en 1987, cuando Botas publica su peculiar glosa a Marcial, hacía varios años que la literatura española había abandonado los espejismos de los canales venecianos y la mitología pop auspiciada por la antología novísima de Castellet. El panorama poético de los ochenta se presentaba polarizado en torno a las llamadas, con pareja imprecisión, poesía de la experiencia y poesía metafísica. Mientras que la primera se articulaba alrededor del anecdotario afectivo y del confesionalismo explícito, la segunda sacrificaba la transitividad comunicativa en aras de un despojamiento retórico que exigía la elaboración del discurso en el límite de la referencialidad.

No obstante, la realidad literaria rara vez se aviene con las categorías preestablecidas por el voluntarismo teórico. Así, la dicotomía experiencia / metafísica pronto se revelaría insuficiente para definir la pluralidad de voces del período. Además de Historia Antigua, de Víctor Botas, donde se incluye «Asturcón», en 1987 se editan libros tan significativos de la línea figurativa como El otro sueño, de Luis Alberto de Cuenca; Suma de varia intención, de Jon Juaristi; Curso superior de ignorancia, de Miguel d'Ors; Diario cómplice, de Luis García Montero, 
y El último de la fiesta, de Carlos Marzal'. Estas obras, que culminan el proceso de normalización lírica iniciado a comienzos de la década del ochenta, sugieren algunos cambios de envergadura con respecto a la imagen mineralizada de la tendencia experiencial. Ésta había cerrado filas en torno a una modalidad subjetiva caracterizada por la dilución de las fronteras entre el sujeto biográfico y el personaje poético, aunque algunos de sus integrantes reivindicaban la ilusión de un correlato autoral (Scarano, 2001: 273) similar al que había promovido Gil de Biedma en «El juego de hacer versos» (Moralidades, 1966). A mediados de los ochenta, el episodio granadino de La otra sentimentalidad (1983), antología-manifiesto que recopilaba poemas y ensayos de Javier Egea, Álvaro Salvador y Luis García Montero, parecía haberse difuminado en las nutridas filas de la experiencia, más heterogénea en su tonalidad lírica y más tibia en sus planteamientos ideológicos ${ }^{2}$. Al margen de sus cimientos estéticos, que remitían al volumen de Robert Langbaum sobre el monólogo dramático en la poesía romántica inglesa, a la paradoja del comediante de Diderot o a la lección del Juan de Mairena machadiano sobre la caducidad histórica de los sentimientos, esta corriente sustentaba su reflexión en los estrechos márgenes del pensamiento débil, cuando no en un encogimiento de hombros anuente con el relativismo posmoderno.

Con todo, los textos adscritos al marbete de la experiencia conformaban un mosaico más diverso de lo que en principio se pudo (o quiso) ver. En los últimos años, esta vertiente se aproxima a una poesía comprometida donde la voluntad cívica convive con una reactivación del yo social, en consonancia con otras propuestas que, desde distintas premisas teóricas, se orientan en la misma dirección:

Según Miguel Casado, 1987 también era un año importante para los autores metafisicios por diversas razones: se edita Edad, de Antonio Gamoneda; muere Aníbal Núñez, uno de los escritores más personales del sesentayochismo, y se imprimen varios libros que rompen con el discurso generacional de la experiencia, como Cántico de la erosión, de Jorge Riechmann, y De barro la memoria, de Menchu Gutiérrez (Casado, 1994: 6-8). A esta nómina habría que sumar Inventario, del propio Miguel Casado, que obtuvo ex aequo con el citado libro de Riechmann el II premio de poesía Hiperión. A propósito de esta irrupción escalonada en la vida literaria, Juan José Lanz declaraba: «En torno a 1986-1987, diversos autores que habian quedado marginados de la tendencia que comenzaba a establecer su dominio, empiezan a publicar una serie de libros (en muchos casos sus primeros libros) que alteran el relato generacional tal como se desarrollaba en aquellos años [...], continuando en cierto modo la diversidad de poéticas de los años anteriores» (Lanz, 1998: 278).

${ }^{2}$ En una entrevista reciente, Juan Carlos Rodríguez, auténtico mumen tutelar del núcleo granadino de la otra sentimentalidad, consideraba el año 1985 como el punto de inflexión en el desarrollo del grupo. A partir de ese momento se certifica la supresión de las fronteras entre la otra sentimentalidad y la poesía de la experiencia, ya que ambas se sintetizan en una única veta de literatura realista: «El grupo creo que se acabó disolviendo pronto, hacia el 85 como mucho, cada uno fue por su lado, aunque Álvaro Salvador opina que duró más como fórmula poética. Yo puse mi parte. Todos estábamos influenciados por el ambiente. La poesía se escribe con las contradicciones de la vida. La literatura no asume las contradicciones》 (Valverde, 2002: s/p). 
la poesía entrometida de Fernando Beltrán; el realismo de indagación de Jorge Riechmann; la escritura del conflicto del grupo valenciano Alicia Bajo Cero, o la estética de la resistencia del sector onubense Voces del Extremo. La convergencia de estos proyectos deriva en una apertura a la colectividad, por más que los modos estilísticos que ahora prevalecen sean ajenos a la compulsión expresionista de la inmediata postguerra. La burla prosaica, el desgarro afectivo y la cotidianidad coloquial coexisten con nuevas realidades temáticas (ecologismo, autopistas de la información, movimientos antiglobalización), elementos de la tradición cultural y estrategias retóricas de ascendencia vanguardista. A su vez, el civismo tiende a liberarse de trabas doctrinarias y de eslóganes políticos. Al lado del materialismo dialéctico de raiz marxista, el método de análisis social por antonomasia en las décadas anteriores, prospera una poesía arraigada (en Miguel d'Ors o Enrique García-Máiquez) muy semejante a la que, en su día, cultivaron los poetas del grupo Rosales (Prieto de Paula, 2002: 381). También la oclusión frente al medio circundante puede encubrir una forma velada de compromiso, basada en el repliegue en las trincheras del yo. Por ejemplo, el escepticismo radical que preconiza el realismo sucio español, en general menos bukowskiano que carvertiano, esgrime un sofisticado acorazamiento ante la laxitud ética del presente. En resumen, este rebrote de poesía social, consciente de hablarle a un lector bien informado, ya no se ve obligado a rebajar su caudal estético, atemperar su contenido ideológico ni realizar vacuos ejercicios de popularismo.

A lo largo de los años ochenta y noventa, los autores emergentes retoman la vocación protestataria del realismo crítico y vuelven la mirada hacia las parcelas menos favorecidas de la vida urbana ${ }^{3}$. La ironía extiende el enfoque descriptivo hacia ambientes marginales que no tenían cabida en la introspección sentimental que propugnaba la primera poesía de la experiencia. No obstante, a medida que esta tendencia va ensanchando su horizonte temático, empiezan a tratarse numerosos aspectos (mendicidad, inmigración, paro, drogadicción) que habían sido relegados de la estampa costumbrista posmoderna. Junto con la crónica de la

${ }^{3}$ No compartimos la opinión de Jaime Siles, quien caracterizaba el discurso lírico de los ochenta como una poesía integrada, complaciente y afín al consumismo, en los antípodas de la crítica disidente postulada por los autores del cincuenta: «Por eso [los miembros de la generación del 80] no hacen poesía de evasión -como hicieron los novísimos- ni de crítica-como el 50 sí la hizo-, sino de entendimiento, de aclimatación y -a veces: muy pocas- de interpretación. La nueva poesia, por lo general y con muy pocas excepciones (Riechmann, Amparo Amorós, Manuel Vilas, Juan Carlos Suñén y Martínez Mesanza) renuncia a criticar el mundo; evita, en la medida en que puede, el interpretarlo; y se conforma -que no es poco- con vivirlo» (Siles, 1991: 168). Esta afirmación, acaso pertinente para algunos miembros de la primera poesía de la experiencia, es desde luego inapropiada a la altura de 1989, cuando muchas de las modulaciones del compromiso (neocostumbrismo, sátira sociopolítica, ironía marginal y acanallada) provenían precisamente de dicha tendencia. 
marginalidad, los escritores actuales reconsideran las expectativas democráticas surgidas a inicios de los ochenta y que desembocaron, a finales de esa década, en lo que Mainer denominaba la «bancarrota de la tradición de izquierdas» (Mainer, 1994: 141). Esta bancarrota conduce a un cuestionamiento de la actitud civil, en sintonía con la perspectiva testimonial que había germinado en los sesenta, aunque acrisolada por contingencias sociológicas que no existían en el momento. En este sentido cabe interpretar la censura del imperialismo estadounidense, la preocupación por el Tercer Mundo, la constatación del fin de las utopías revolucionarias y la denuncia del belicismo, si bien el escenario de Vietnam se sustituye por el de la antigua Yugoslavia y por Oriente Medio.

La ampliación del abanico argumental en los poetas de los ochenta no implica la renuncia a los procedimientos habituales en su plasmación artística, tales como la primacía de la narratividad sobre la propagación de contenidos ideológicos, el remedo intertextual o el descriptivismo urbano. Estos autores propenden bien hacia la desautomatización del mensaje, mediante el acercamiento al epigrama o a la sátira, bien hacia la transcripción imparcial de la realidad, mediante la inserción de noticias e informaciones periodísticas a la manera de collage pop. Asimismo, el pacto de lectura que había nacido al socaire de la figuración realista no sufre modificaciones de peso en esta etapa, salvo por un incremento del escepticismo en lo relativo a la capacidad representativa del lenguaje. La emanación confesional se dirige a un receptor cómplice y configura un hablante-oyente ideal como trasunto del estereotipo comunicativo chomskyano (Sánchez Torre, 2002: 53).

\section{Entre el epigrama crítico y la sátira neocostumbrista}

Los escritores de los ochenta entroncan con los matices burlescos del epigrama y de la sátira, cuya configuración genérica les permite un acercamiento a la realidad filtrado por el cedazo de la herencia literaria ${ }^{4}$. Estos autores conjugan

+ En sus orígenes, el epigrama era una breve pieza de carácter funerario, procedente de la poesía trenética griega o tal vez de las inscripciones sepulcrales fenicias. Los epigramas más antiguos eran inscripciones dedicatorias y funerarias cuyo esquema estructural se hallaba muy codificado. En primer lugar, constaban de un elogio de la persona fallecida; en segundo lugar, se daba noticia sobre su muerte; en tercer lugar, se citaba el nombre del constructor de la tumba, y, por último, se solía incluir una maldición a quien dañase o destruyera el monumento. Más tarde, a esta función consolatoria, propia del epigrama arcaico, se añade una función literaria, que ocupa un lugar secundario. Así lo manifiestan los epitafios en primera persona, los cenotafios en los que la tumba o el propio muerto se dirigían al caminante, $y$ las inscripciones en las que hablaba una figura alegórica. A partir del siglo IV a. C. el epigrama alude a un tipo de poema breve y lapidario que se definía por poseer una cierta punta o mordiente en los versos finales, aunque sin el contenido satírico inherente a su plasmación latina. La forma métrica más habitual, que acabó imponiéndose al hexámetro después de alternar largo tiempo con él, era el dístico elegíaco. Ya en el periodo helenístico, los epigramas se agrupan en colecciones como la famosa Antología Palatina, que reunía cerca de 3700 epigramas. 
las aportaciones formales de los poetas de la escuela de Barcelona (Carlos Barral, José Agustín Goytisolo, Jaime Gil de Biedma) con la sentenciosa agudeza de los epigramistas latinos (especialmente, Marcial). De los primeros recogen el humorismo autoirónico, la vocación memorialista y la desafiante subjetividad que tiñe sus versos, aquí y allá, de una pátina de desencanto existencial. De los segundos, la condensación expresiva, la concentración prosódica y la intensidad en los desenlaces de los poemas. Acaso por su mayor proximidad con el grupo del cincuenta y con ciertas derivaciones de la poesía civil, los integrantes originarios del 68 desarrollan la potencialidad crítica del epigrama y de la sátira, al tiempo que proponen una revisión desencantada de los emblemas del realismo. Así se observa en libros como Una educación sentimental (1967), de Manuel Vázquez Montalbán; Teatro de operaciones (1967), de Antonio Martínez Sarrión, o Fábulas domésticas (1972), de Aníbal Núñez, que remitía a las «Fábulas para animales» (Grado elemental, 1962) de Ángel González.

Desde mediados de los años setenta, el regreso al universo clásico es indisociable de la restauración de un humanismo que se basa en el equilibrio entre los aspectos artísticos y vitales que se vierten en el poema. De acuerdo con esta reivindicación ha de entenderse el reencuentro con los maestros (Catulo y Marcial) y con las fuentes (el epigrama, la sátira y la elegía) de la tradición grecolatina. Más allá de la utilización ocasional de la referencia mitológica o del apunte erótico, se gesta una nueva cosmovisión vinculada con una manera personal de interpretar el clasicismo ${ }^{5}$. Tanto la propensión autobiográfica como el reflejo costumbrista de determinadas parcelas de la sociedad se pueden explicar por la propia dinámica generacional. Una vez que el esteticismo novísimo se había calcificado en unos engranajes creativos que parecían funcionar de forma exenta a la materia lírica, los escritores de los ochenta no se limitan a prolongar la incursión en los mitos culturales que había animado la poesía del 68 , sino que tratan de incorporar dichos mitos en la realidad cotidiana. No es de extrañar, por tanto, que el neocostumbrismo se ocupe de las mismas esferas que el epigrama de Marcial y la sátira de Horacio: la caricatura de los malos poetas, la amonestación a los políticos corruptos y la ridiculización de los hipócritas y oportunistas ${ }^{6}$.

${ }^{5}$ El culturalismo de cita externa que había cuajado en los primeros años setenta se sustituyó en la segunda mitad de la década por un culturalismo de cita interna, compatible con la rehumanización lírica. Sin embargo, la insistencia en un parecido magisterio poético desembocó, hacia 1980, en un neoclasicismo manierista y abigarrado que conciliaba el grecismo melancólico de Cernuda, el vitalismo de los poetas de Cántico y el erotismo crepuscular y mitológico de Cavafís. A este respecto, Fernando R. de la Flor hablaba de un «neo-neo-clasicismo» que ya no se contentaba con recuperar el tiempo histórico como presente antropológico, sino que aspiraba a «conquistar un presente antiguo, en el que reconocerse y reconocernos como sujetos de una fascinación químicamente calculada» ( $R$. de la Flor, 1983: 64).

"Prieto de Paula subrayaba el regreso a la sustancia anecdótica y al detallismo argumental en los autores de los ochenta: «El neocostumbrismo es, por ello, el ámbito en que se encuentran compo- 
Varias composiciones de esta época muestran un trasvase con los tonos y motivos del epigrama. Así se percibe en el cuaderno Aguas mayores y menores (1985) y en Historia Antigua (1987), de Víctor Botas. En la obra de Botas conviven los poemas que descienden del epigrama jocoso instituido por Marcial en la cultura latina y aquellos otros que entroncan con los ioci o nugae de Catulo. De ello dan ejemplo «Epigrama» (Aguas mayores y menores) y «Variación sobre un tema de Catulo» (Historia Antigua). Por una parte, «Epigrama» critica a un adulador mediante la imitación de la estructura bipartita del epigrama clásico y el calco de las características esenciales del género: la falsa complicidad con la víctima del ataque, la tensión expresiva, el giro inesperado y el efecto chistoso, resumido en el prosaísmo escatológico de los últimos versos. Por otra parte, «Variación sobre un tema de Catulo», libremente inspirado en el carmen LII del veronés contra Nonio y Vatinio, reprueba la conducta de un trepador social. Botas decide dejar en el anonimato a su interlocutor para que éste no perdure en sus versos, aunque sea cargado de connotaciones negativas. A pesar de que la omisión del objeto del ataque quiebra el paralelismo intertextual con Catulo, este recurso adquiere pleno sentido en la producción de Botas. El marco clásico le permite articular una invectiva que alcanza congruencia al incardinarse en su pensamiento sobre la pervivencia del arte y de la poesía (Botas, 1999: 254):

Te creerás gran cosa tan sólo porque fuiste, trepador, ascendiendo quién sabe con qué argucias y zalemas.

Tranquilo, que no voy a nombrarte; no me perdonaría nunca que se pudiera salvar algo de ti en el raro tiempo.

Sin embargo, no todos los escritores que cultivan el epigrama manifiestan este afán de diálogo con los autores del mundo clásico. La reelaboración del epigrama a partir de los años ochenta conlleva progresivamente la pérdida

nentes poco frecuentes en la poesía más en boga [en el marco generacional del 68]: cierto realismo y transitividad comunicativa, frente al hermetismo, al esencialismo y al ensimismamiento; inclinación ética, frente al evasionismo y la segregación entre moral y arte; veta humorística y satírica, y a veces liviandad temática, frente a la seriedad enfática y al hinchado trascendentalismo; compromiso con lo contiguo e inmediato, frente al compromiso sólo con lo sublime y frente a la ausencia absoluta de compromiso...) (Prieto de Paula, 1998: 255). 
de su acotación espaciotemporal y la atenuación de sus mecanismos retóricos y estructurales. Al tiempo que las marcas cronológicas se difuminan, la anécdota se encuadra en un indefinido decorado pretérito, que actúa como metáfora del presente. De este modo, las preocupaciones expresadas son un reflejo de las que afectan a nuestra sociedad. Así sucede en «Estela victoriosa» (Europa y otros poemas, 1990), de Julio Martínez Mesanza, que medita sobre las paradojas de las democracias modernas, y en «Impuestos» (Un hombre no debe ser recordado, 1992), de Juan Carlos Suñén, cuya ubicación en el pasado grecolatino obedece menos a un impulso arqueológico que a una voluntad, apenas velada, de indagación en la actualidad.

La faceta funeraria y la faceta burlesca del epigrama se funden a menudo en una sola composición ${ }^{7}$. Así ocurre en «Requiem æternam donet tibi» (Diario de un poeta recién cansado, 1985) y en «Spoon River, Euskadi» (Suma de varia intención, 1987), ambos de Jon Juaristi. Este último se construye sobre una doble referencia literaria. Por un lado, conversa con el libro Spoon River (1915), de Edgard Lee Masters, una galería de ficticias estelas sepulcrales que representaban a los habitantes de una pequeña población del Medio Oeste estadounidense. Por otro, conecta con los epigramas de la Antología Palatina en los que Lee Masters se inspiró para sus retratos de los ciudadanos de la imaginaria Spoon River $^{8}$. Aunque en este caso la técnica inscripcional se ciñe al modelo de dicción

${ }^{7}$ El maridaje entre la inscripción funeraria y el epigrama crítico, que ya convivieron en la Antigüedad clásica, alcanzó un gran rendimiento estético en la poesía del Barroco español. Así se observa en composiciones como «Epitafio de una dueña, que idea también puede ser de todas», de Francisco de Quevedo; «A un mal poeta (epitafio)» y «A una dama en exceso flaca (epitafio)», de Alonso de Castillo y Solórzano; «Epitafio a un mozo preciado de lindo» y «Epitafio a un poeta culto», de Jacinto Alonso Maluenda, etc. Al tiempo que respetan los cauces formales del epigrama sepulcral, en ocasiones con una intención paródica, estos poemas enlazan con el epigrama satírico a través del retrato de determinados arquetipos sociales. A pesar de que se mantienen ciertos motivos originales del género, como la crítica a la mujer instaurada por Semónides en su «Catálogo de las mujeres», se agregan nuevos objetos de burla; por ejemplo, el poeta culterano. La censura de los excesos literarios se relaciona con la que había dirigido Cristóbal de Castillejo a los autores italianizantes de la primera mitad del siglo XVI.

"El mismo referente se encuentra en «Variación sobre un tema de Edgar Lee Masters» (El laboratorio, 2000), de Bruno Mesa. Según confiesa el autor, esta composición nace del deseo de invertir el sentido de los tres últimos versos del poema «William Jones》, de Lee Masters. La traducción de estos versos dice así: «Cubridme, cubridme con conchas del río. / Viví con asombro, adorando la tierra y el cielo. / He participado en el eterno desfile de la vida sin fin». En cambio, el dechado moral de la versión de Bruno Mesa se inclina hacia el escepticismo y el vacío vital que predoninan en el horizonte posmoderno. De esta manera se explica el añadido del verso que clausura la pieza: «No me cubráis con conchas del río. / Enterradme desnudo y sin rituales / en una noche sin luna de un día cualquiera. / Viví sin asombro, odiando la tierra y el cielo. / Nunca participé en el eterno desfile de la vida. / Fui una sombra que camina sobre la sombra del mundo» (Mesa, 2000: 72). 
en el que habla el difunto, Juaristi transfiere el sentimiento individual del epitafio a un sujeto colectivo, un nosotros que engloba al pueblo vasco. La interpelación interrogativa al viajero que pasa junto a la tumba aproxima el poema al epigrama dramático de Marcial, que se componía de una estructura tripartita: exposición del tema, pregunta del interlocutor y desenlace mordaz. Con todo, Juaristi respeta el esquema bimembre originario, pues omite la presentación inicial. El texto se concibe como la suma de una pregunta y una respuesta, ambas pronunciadas por el personaje colectivo (Juaristi, 2000: 72):

¿Te preguntas, viajero, por qué hemos muerto jóvenes,

y por qué hemos matado tan estúpidamente?

Nuestros padres mintieron: eso es todo.

La hibridación entre el epigrama satírico y el funerario se observa con especial nitidez en «Bajo la llama (Tumbo del soldado desconocido)» (Otros labios me sueñan, 1992), de Jesús Munárriz, que aborda la cuestión del antimilitarismo. El poema de Munárriz contraviene la imagen arquetípica del soldado aguerrido, a través de la deformación del héroe que protagoniza la pieza. Este largo monólogo se sitúa a medio camino entre la sátira y el epigrama. Con la primera se relaciona a causa de su extensión y de la diversidad de procedimientos estilísticos que despliega el autor: interrogaciones retóricas ( «-¿Desconocido? El padre / del que me enterró aquí, debajo de la llama, / será el desconocido»), encabalgamientos léxicos («Desconocido, claro, ni mi madre / me hubiera conocido»), enumeraciones caóticas («me sacaron de casa, me vistieron de caqui, / me endilgaron un arma»), comparaciones hiperbólicas («la cosa era como aguantar / una tormenta en descampado», «me despanzurró como a un huevo un martillo»), expresiones coloquiales, frases hechas y diminutivos irónicos («mala leche», «cuando toca, toca», «me plantó la llamita»). No obstante, enlaza con el epigrama por la fórmula que cierra la composición, donde habla el soldado muerto en el campo de batalla. En la conclusión, siguiendo la costumbre del epigrama funerario latino, el personaje se encomienda al caminante / lector, reclama su atención y pide levedad a la tierra que lo alberga (Hickson, 1993: 102-103). Sin embargo, Munárriz altera las prescripciones de este género al introducir la petición del sujeto literario en un contexto claramente paródico. El soldado desconocido no solicita una oración o unas palabras para el descanso de su alma, sino que exige ser privado de todos los símbolos que privilegian su condición de soldado sobre la de individuo". Por tan-

"La alternancia entre la concisión epigramática y la severidad elegíaca reaparece en «La breve historia de un soldado» (Por la secreta escala, 1994), de Javier Almuzara. En este pocma, dedicado a Martínez. Mesanza, escuchamos el monólogo de un feroz guerrero, descrito con pinceladas muy distintas a la comicidad y al tono crítico que presidian el tex to de Munárriz. Ahora, el valiente soldado 
to, el texto es el resultado de una forma mixta doble, mezcla de la sátira política con el epigrama inscripcional, mezcla de las convenciones religiosas latinas con la invención del escritor contemporáneo (Munárriz, 1992: 66):

Apaguen ese fuego, por favor; arranquen de mi polvo esas letras de bronce.

Más leve es de civil la eternidad.

En los aledaños del epigrama, los autores del período escriben una sátira que afecta a algunos tipos relacionados con los que poblaban las galerías costumbristas del siglo XIX: los malos poetas, los falsos intelectuales, los arribistas, los políticos corruptos o los ejecutivos ambiciosos que proliferaron a finales de la década del ochenta. La dimensión ética y el esquema elocutivo compartidos por quienes cultivan este género conectan con la sátira latina y barroca. La primera incorpora una perspectiva indulgente y poco virulenta, que intenta hacer compatible el distanciamiento emotivo de la sátira horaciana con un estilo en apariencia desaliñado y con un lenguaje coloquial, afín a la sentenciosidad epigramática de Marcial. Por otra parte, la influencia de la sátira barroca se resuelve en una modernización burlesca de los temas mineralizados a lo largo del Siglo de Oro: aurea mediocritas, desprecio de las ambiciones cortesanas, canto a la vida retirada, etc $^{10}$. A menudo se produce un solapamiento entre la sátira y el epigrama, pues ambos coinciden en su voluntad crítica, en su transitividad comunicativa y en su interés por capturar ambientes de la vida cotidiana. No obstante, la sátira permite

que ha luchado en todas las batallas y que ha llegado a convertirse en un terrible mercenario busca en vano la paz después de los combates en que ha participado. El vuelco epigramático de esta pieza se sintetiza en el verso final, cuando descubrimos que el soldado que rememora los hitos esenciales de su vida está hablando, en realidad, desde el túmulo en que ha sido enterrado. Almuzara resume la vacuidad de una vida entregada a la guerra a partir de un descenso, entre esperpéntico y macabro, a la iconografia escatológica del Barroco: «Ahora muchos desean / descansar, como yo, de los combates, / y no sabré advertirles, / que aquí tampoco hay paz, / que cuando ya no puedo defenderme, / me siguen atacando, / sin tregua, los gusanos» (en García Martín, 1998: 202).

1" La rehabilitación de la epístola satírica a lo largo de los años ochenta actualiza las muestras de este género en el Renacimiento y en el Barroco. En el Renacimiento, la epístola moral solía hallarse bastante codificada en lo relativo a sus temas (beatus ille, prisión dorada, huida de la corte) y formas métricas (los tercetos encadenados, cuya fluencia discursiva a veces se abandona en favor de ciertos meandros o digresiones aisladas). Ya en el Barroco, la epístola adquiere una mayor fosilización tópica y estructural, tal como se observa en «A Fray Pedro Maldonado, por la constancia», de Francisco de Medrano; «A don Francisco de Eraso», de Bartolomé Leonardo de Argensola; «Epístola Il a Heliodoro o soledad del gran duque de Medina Sidonia», de Pedro Espinosa, y en la «Epístola moral a Fabio», de Andrés Fernández de Andrada. Por su parte, en la «Epístola satírica y censoria contra las costumbres presentes de los castellanos, escritas a don Gaspar de Guzmán, Conde de Olivares, en su valimientos, Quevedo se apropiaba de la invectiva crítica y belicosa que habian desarrollado en la literatura latina Lucilio, Persio o el primer Juvenal. 
una graduación tonal y una variedad de recursos que el epigrama, debido a su brevedad y a lo codificado de su estructura, es incapaz de ofrecer. En detrimento de la serenidad y el equilibrio clásicos, los autores de los ochenta utilizan voces conversacionales, incisos parentéticos y desenlaces distendidos.

En este terreno se acotan algunos poemas que remedan la epístola moral o censoria del Siglo de Oro: «La malcasada» (El otro sueño, 1987), de Luis Alberto de Cuenca; «El autor amonesta a un amigo» (El último de la fiesta, 1987), de Carlos Marzal, y «Sátira primera (a Rufo)» (Los paisajes domésticos, 1992), de Jon Juaristi. Estos textos recurren a esquemas métricos prestigiados por la herencia literaria: «La malcasada» y «Sátira primera (a Rufo)» están escritos en endecasílabos blancos, en tanto que «El autor amonesta a un amigo» es una silva arromanzada. Igualmente, Marzal alude a «mi bien amado Fabio», de acuerdo con el sobrenombre poético acuñado por Horacio y difundido en el Siglo de Oro. Las tres composiciones dialogan con figuras de la tradición - una mujer malmaridada, un joven Don Juan restaurado en ciudadano respetable y un vate local-, que se subordinan al retrato de los gremios del presente: la cofradía de los ejecutivos en «La malcasada»; la turba nocturna, discotequera y acanallada en «El autor amonesta a un amigo», y los círculos académicos en «Sátira primera (a Rufo)».

El cariz circunstancial de «La malcasada» remite a la engañosa futilidad de «A una dama muy joven, separada» (Moralidades), de Gil de Biedma. De hecho, La caja de plata (1985) y El otro sueño señalan una inflexión en la evolución estética de Luis Alberto de Cuenca. A partir de estos libros, la suntuosidad culturalista y la recreación de los mitos clásicos que habían predominado en su obra anterior se sustituyen por la fabulación de la vida cotidiana. El autor se adueña de una voz personal, intimista e irónica, que matizará en sus siguientes entregas: El hacha y la rosa (1993), Por fuertes y fronteras (1996) y Sin miedo ni esperanza $(2002)^{11}$. Los primeros versos de «La malcasada» concuerdan con la exposición del tópico literario, tal como se infiere de la utilización del estilo indirecto y de

"Tras los clichés librescos y el exotismo de cartón-piedra que proyectaban Los retrutos (1971), Elsinore (1972) y, parcialmente, Scholia (1978), la trayectoria del autor dio un marcado vuclco con $\mathrm{La}$ caja de plata. A este respecto, anotaba Luis Alberto de Cuenca: "Con Amour fou [La caja de plata] me di cuenta de que algo se estaba inaugurando en mi poesía: por un lado, el poema era un homenaje al concepto surrealista de amor loco, interpretado desde una perspectiva folclórico-literaria y con un molde alejandrino; por otro lado, el poema marcaba la renuncia de su autor a ciertas locuras culturales a cambio de otras locuras mundanas» (Gutiérrez Carbajo, 1995: 130-131). En un artículo anterior, el pocta había criticado la utilización superficial de la cultura por parte de los autores de su generación: «No nos apetecía escribir nada que no tuviera unos orígenes culturales, librescos. La vivencia (esa horrible palabra) sólo venía después, a impedir que el plagio fuese perfecto. Entendíamos la poesía tal como la cntendian los antiguos alejandrinos: momentánea y circunstancial, festiva, intrascendente, divertida e inútil» (Cuenca, 1979-1980: 248). 
la repetición del anafórico «Me dices que». En cambio, los que sirven de broche al monólogo dramático no pueden asociarse con la gravedad moral del mensaje estoico. En ellos, el poeta no le aconseja a su amiga, como sería predecible, resignación y asepsia espiritual. Al contrario, sin renunciar a la entonación conativa, hace gala de una displicencia netamente contemporánea, que se condensa en la enumeración final (Cuenca, 1999: 138):

La nostalgia es un burdo pasatiempo.

Vuelve a ser la que fuiste. Ve a un gimnasio, píntate más, alisa tus arrugas

y ponte ropa sexy, no seas tonta, que a lo mejor Juan Luis vuelve a mimarte

y tus hijos se van a un campamento, $\mathrm{y}$ tus padres se mueren.

Por su parte, en «El autor amonesta a un amigo», de Carlos Marzal, se auscultan los ecos tanto de la sátira horaciana (I 3) como de la epístola del Barroco. En esta composición, la exaltación de la amistad y el retiro de las pasiones mundanas se contemplan desde el tamiz de la parodia. El poeta valenciano presenta a un personaje de inclinaciones crapulosas, supuestamente redimido gracias al amor de una muchacha y apartado de los ambientes nocturnos que solía frecuentar. No obstante, Marzal manifiesta su escepticismo sobre la sinceridad del arrepentimiento de quien quizá sólo intenta «jugar a ser trapense», y vulnera los designios de la sátira latina al amonestar a su amigo por haberse acogido el ideal de la aurea mediocritas y haber abandonado la búsqueda incesante del hedonismo. En su envío, la pieza adopta una repentina sobriedad, que asiente con la lección de la vanitas barroca (Marzal, 2003: 55):

Amado Fabio, sea como fuere, si no felicidad, que es bien mudable, te envío plenitud, que permanece. Hagas lo que hagas, al final, sabemos que todo habrá de ser indiferente. Se perderán tus juegos y los míos, como todo se pierde.

De distinto sesgo es «Sátira primera (a Rufo)», que recoge la crítica de las ambiciones literarias. Este tema se bifurca, a su vez, en la caricatura de un poeta local, mencionado por el sobrenombre de Rufo, y en la estampa de la vida académica. En el poema, las inquietudes habituales de Juaristi se vinculan con la entonación humorística, el acento cívico y el homenaje, entre jocoso y sincero, a los antiguos compañeros de viaje. Además, cabe reseñar la adaptación al ritmo endecasílabo y los ocasionales juegos de rimas, que a menudo transigen con lo 
deliberadamente ripioso: «Otra gente / parece preferir ahora Vicente». También desaparece la veta agria y mordaz, fruto de la retractación de antiguas posturas ideológicas, que a veces se filtra en los versos del autor. Juaristi pone en práctica la reconstrucción experiencial que había sugerido en su artículo «El pacto realista», donde indicaba que la poesía no podía existir al margen de la temporalidad, la emoción y la ironía, entendida esta última como un modo de catarsis sentimental (Juaristi, 1994: 25). «Sátira primera (a Rufo)» ha de interpretarse como un ejercicio poético que oculta, tras su aparente ligereza y banalidad, una honda reflexión sobre las mutaciones ocurridas en la sociedad española durante los últimos años. Con todo, la sátira funciona en su dimensión literaria. El Rufo del título, apelando a una antigua amistad con el escritor, le pide recomendación en un certamen en que éste participa como jurado. Después de recordar las horas pasadas en la infancia y juventud con el citado Rufo, Juaristi decanta el poema hacia un desenlace de filiación epigramática, en que insinúa la imposibilidad de que su amigo se haga con el galardón al que aspira (Juaristi, 2000: 149):

$$
\text { Cree, Rufo, }
$$

que nada tengo contra ti. Al contrario,

te recuerdo con franca simpatía.

Es cierto que arruinaste mi mecano, que me rompiste el cambio de la bici, que le contaste a mi primera novia lo mío con tu prima, la Piesplanos. Eras algo indiscreto, pero todos tenemos unos cuantos defectillos. Veré qué puedo hacer. No te prometo nada: somos catorce y, para colmo, corre el rumor de que Juan Luis Panero.

En suma, el epigrama y la sátira suponen para los autores de los ochenta un tipo de enunciación que evita tanto la severidad didáctica como la lacrimosidad confesional, porque compatibiliza el reflejo de la realidad inmediata con un cierto alejamiento emotivo. Ya sea a través de la conversación con los clásicos de la Antigüedad grecolatina (en Botas y Munárriz), de la disolución del decorado referencial en aras de cierta plasticidad abstracta (en Martínez Mesanza y Suñén) o de la aproximación al neocostumbrismo (en Cuenca, Marzal y Juaristi), las fuentes grecolatinas plantean la posibilidad de renovar con la poesía social sin necesidad de inclinarse ante los engranajes oxidados de una antigua retórica.

\section{Collage, intertextualidad, procedimientos vanguardistas}

La comunicación con los géneros y tópicos grecolatinos no es la única vía para la regeneración del compromiso. Aunque la musa española de postguerra 
logró perfilar un estilo coherente con la idea de la poesía como «un arma cargada de futuro» -supresión del ornamentalismo, indagación en la realidad inmediata, revisión de las expectativas literarias vigentes-, esta voluntad de despojamiento redundó en cierta pobreza. La depuración retórica acabó por producir otra retórica distinta, pero igual de desvitalizada que la de las corrientes contra las que estos autores reaccionaban. Las restricciones estilísticas y la reiteración ad nauseam de unos mecanismos similares explican por qué los escritores de los ochenta intentan desvincularse progresivamente de esta forma de entender la lírica.

Sin embargo, la poesía civil no permaneció inalterable a lo largo de los años, sino que se fue plegando a las modulaciones históricas y a los requerimientos estéticos de las etapas por las que atravesó ${ }^{12}$. Al final de su trayectoria, los mejores autores de la escuela socialrealista (Celaya, Otero, Hierro) llegaron a asumir una perspectiva metaliteraria donde los contenidos cívicos se vertían en un discurso emparentado con otros espacios culturales aledaños: la columna periodística, el artículo de opinión, la crónica política, etc. En este momento, la renovación del compromiso coincide con el giro escéptico de las primeras producciones sesentayochistas. Ambas tendencias cuestionan el principio de autonomía artística postulado por las vanguardias, rechazan la descripción fidedigna de la realidad y ponen en tela de juicio la capacidad denotativa del signo lingüístico. En consecuencia, conectan con el relativismo, la fragmentariedad y la dislocación estilística (Scarano, 2001: 275-276).

Dentro de este ámbito experimental, ya en la década del noventa, algunos autores extreman la actitud antirretórica, hasta tensar los límites de la construcción poética. Al mismo tiempo, añaden implicaciones pragmáticas a la naturaleza meramente ficcional del poema. De este modo, el desenmascaramiento ideológico revierte en un desenmascaramiento retórico (Sánchez Torre, 2002: 49-50). A ello contribuye la reactivación de una línea metadiscursiva que le permite al poeta explorar las imbricaciones entre texto y contexto, entre lenguaje y objeto, entre arte y mundo. Aun así, las formas de intertextualidad que encontramos en la poesía del período deben menos al afán disolvente de las vanguardias que a los recursos de agregación verbal que caracterizaron a los seniors del 68. Éstos avanzaron en el descubrimiento de nuevos métodos de expresión poética que se sustentaban

${ }^{12}$ Guillermo Carnero distinguia hasta ocho bloques temáticos sucesivos en la poesía social: 1) referencia a la guerra civil; 2) crónica de la represión; 3) sátira de la integración, por miedo o conveniencia; 4) solidaridad afectiva o ideológica con el proletariado; 5) voluntad de fuchá política; 6) agitación política; 7) temá de España; 8) internacionalización de la poesía social. El desplazamiento hacia un ámbito supranacional puede interpretarse como correlato de la situación política española en los años sesenta. La atenuación de la represión política y el desarrollismo económico provocaron que los autores buscasen nuevos enemigos en el capitalismo internacional, la amenaza atómica o el imperialismo avasallador de los Estados Unidos (Carnero, 1989: 315-319). 
en la sensibilidad camp entronizada por «la papisa S. S.» (Susan Sontag), según se decía en el prólogo de Nueve novísimos poetas españoles (1970) (Castellet, 2001:31) ${ }^{13}$.

Los autores de los ochenta enriquecen su estilo con matices ajenos al lirismo convencional. Una de estas aportaciones es la mezcla de la poesía y el ensayo, que alterna la cadencia reflexiva y el trasfondo egotista. Con esta finalidad, se incluyen tecnicismos identificados con determinados sociolectos, términos procedentes de diversos campos semánticos y préstamos idiomáticos. Ejemplo de ello es la incorporación del lenguaje publicitario para criticar la tecnocracia new age y la intromisión de los medios de comunicación en las relaciones interpersonales. En este territorio se inscriben algunas composiciones donde la manipulación del lenguaje de la publicidad no constituye la aspiración primordial del poema, sino que es una coartada para formular una denuncia más compleja. Cuando el consumismo se ha implantado en todas las facetas de la realidad, la desmitificación de sus dispositivos publicitarios resulta obvia, pues el propio medio se encarga de subvertir el sentido mitificante que antaño tenía esta clase de discursos. Para estos escritores, la vacuidad de los mensajes comerciales metaforiza la inanidad de los valores difundidos en la era posmoderna. Dicha tesis se expone abiertamente en «De la publicidad» (Problemas de doblaje, 1990), de Aurora Luque, en que la contemplación de un reportaje de moda se eleva hacia una especulación sobre los tópicos literarios y sobre la precariedad de las esperanzas actuales (en Benegas y Munárriz, 1998: 414) ${ }^{14}$ :

Perfumada de Armani

la nada es altamente soportable.

Por su parte, en «Noticia del día» (La semana fantástica, 1999), de Fernando Beltrán, la relectura del código publicitario se resuelve en una degradación prosaica. La exaltación de una determinada marca de coches no pretende anteponer la belleza del automóvil de carreras a la Victoria de Samotracia, tal como proclamaban los futuristas italianos. En cambio, la enumeración de las virtudes de la marca

1. La utilización del camp en los seniors de Nueve novisimos se ha asociado en ocasiones con los ejercicios memorialísticos de los poetas del 50 . No obstante, la memoria de los autores del 50 era narrativa; la de los seniors del 68 es fragmentaria. Además, éstos agregan, al componente estrictamente personal y autobiográfico del cincuenta, abundantes ingredientes extraídos de la subcultura de la época, como canciones y eslóganes (Lanz, 2000: 425).

${ }^{14}$ La plantilla publicitaria y el esguince humorístico del poema se asocian con «Paco Rabanne: In Memoriam» (Reverso, 1988), de Fanny Rubio. Sin embargo, el tema de la composición, los espejismos del deseo, sintoniza con la evocación sugerente de los anuncios televisivos: «te debo confesar que fue la huella del perfume que se extendió en tu cuerpo lo que yo amé // y él sólo fue partícipe y testigo de la hermosa mentira» (Keefe Ugalde, 1991: 142). 
automovilística parodia la porosidad del lenguaje consumista. El título del poema, que otorga el rango de noticia a lo que no es sino propaganda vacía, se orienta en esta dirección. También las abundantes elipsis, síncopas y reiteraciones, así como la utilización de un léxico especializado, resaltan el pastiche del anuncio televisivo (Beltrán, 1999: 39-40) ${ }^{15}$ :

Y, al apresto, la pintura y el barniz,
en total ocho capas,
con el fin de que el tiempo
se deslice sobre tu coche
sin dejar huella.
Belleza, seguridad, progreso.
No te imaginas lo que Citröen
puede hacer por ti.

Una práctica similar a la presencia de registros especializados en el poema es la inserción de materiales paraliterarios: trabajos académicos, telegramas, anuncios periodísticos, cartas y, en general, moldes genéricos distintos a la poesía. Sin embargo, la inclusión de ingredientes extratextuales rara vez se produce en un marco vanguardista, lindante con el collage dadaísta o con el cadáver exquisito propugnado por los surrealistas. La misión de estos textos no es exhibir el artificio de su construcción, sino, al contrario, reflejar la trama de lenguajes que convergen en el entorno cotidiano. La presencia de voces orales e incisos conversacionales dotan a la elocución de una aparente naturalidad, como se observa en «Oferta de empleo» (Partes de guerra, 1994), de Juan Bonilla. Este poema utiliza la falsilla de los anuncios por palabras para censurar las desigualdades del universo laboral. Bonilla desvela la voluntad irónica que preside su composición gracias a la corrupción del esquema retórico adoptado. A este propósito obedece la selección de un lenguaje denotativo, pero que juega con los patrones periodísticos (anuncios de empleo, servicios de contactos) y que ofrece una profusión de datos (domicilios, nombres propios, números de teléfono) en apariencia verificables. Los últimos versos justifican la lectura de «Oferta de empleo» como una diatriba contra el nepotismo profesional y contra la segregación sexual que pervive en ciertas esferas laborales (Bonilla, 1998: 45):

Preciso señorita de ojos negros, melena negra derramada en cascada por la espalda, uno setenta y tres de altura,

${ }^{15}$ Esta crítica se prolonga en «Dixán» (Las afueras, 1997), de Pablo García Casado, y en «Solo en casa» (recogido por Luis Antonio de Villena en La lógica de Orfeo, 2003), de Javier Rodríguez Marcos. Ambos diluyen la anécdota sentimental que les sirve de soporte en el dominio de los eslóganes publicitarios y en las imágenes de los spots televisivos. 
estudiante de cuarto de Arquitectura,

domiciliada en Vía Layetana, 17, octavo C, Barcelona,

su teléfono ha de ser el 3456781 .

Imprescindible que haya leído tres veces

La Gran Eulalia de Paola Capriolo

y que cumpla años (24 esta primavera)

el 17 de abril.

Se ha de llamar Marta Trullols Aymé.

Se le propone salir a tomar algo

(aunque no sea en serio).

Interesadas llamar al 4531704.

Absténganse quienes incumplan uno solo

de todos estos requisitos.

Otra fórmula frecuente en los autores de los ochenta es la reelaboración de artículos de opinión sobre asuntos de actualidad, que expresan el malestar del poeta por el estado del mundo y por la omnipresencia del mercantilismo en la sociedad contemporánea. Estas composiciones sacrifican los vuelos metafóricos y los juegos verbales en aras de un lirismo descarnado, en ocasiones concomitante con la áspera narratividad del realismo sucio y en otras con la transparencia conductista. Este recurso cobra protagonismo en El dia que dejé de leer $E L$ $P A i S$ (1997), de Jorge Riechmann, cuyo título subraya la relevancia que alcanza el registro periodístico en el libro. Riechmann indica que el germen del poema que abre el volumen, «El bello sueño del trabajo estable», estaba comprendido en un artículo de opinión ajeno que el escritor ha citado textualmente en su orden original, después de tachar la información sobrante ${ }^{16}$. Sus manipulaciones se reducen, pues, a la eliminación de algunos fragmentos del artículo inicial, a la supresión de la puntuación y a la transcripción de la composición en letra mayúscula, que la aproxima en el plano formal al manifiesto vanguardista. A través de la disposición de los párrafos como un conjunto de eslóganes que pautan la fluencia discursiva, el recorte periodístico se integra en un particular collage literario. Por lo demás, la plasmación objetiva sugiere aquí una crítica a la feroz competencia empresarial, al neoliberalismo capitalista y a la globalización mercantil. En suma,

16 Apostilla Riechmann: «Como es bien sabido, en muchos casos el poeta es mero amanuense de potencias inspiradoras que le sobrepasan. Este poema estaba contenido en el artículo de don Jaime García Añoveros - catedrático de Hacienda en la Universidad de Sevilla- titulado El bello sueño del trahajo estahle: no tuve más que tachar el texto sobrante. Por tanto, todos los fragmentos son citas textuales y su orden se ha respetado escrupulosamente» (Riechmann, 1997: 15). 
Riechmann se sirve del artículo de opinión para esbozar una tesis sociológica. El autor destaca la incongruencia de que la expansión económica haya de producirse en detrimento del nivel de vida de los individuos, tal como ponen de relieve las últimas frases del poema (Riechmann, 1997: 14-15):

EN ESTAS CIRCUNSTANCIAS EL IDEAL DE UN EMPLEO A LO LARGO DE UNA VIDA CON TODO LO QUE LA VINCULACIÓN A UN SITIO APORTA COMO CALIDAD DE VIDA Y RELACIONES PERSONALES ES UNA UTOPÍA

TODO CAMBIA UNA ECONOMIAA LIBRE ES UNA ECONOMÍA DE CAMBIO

\section{LA LIBERTAD}

TRAE MUCHAS INCOMODIDADES

PERO DEBERÍAMOS SABER QUE AL ENTRAR EN LA C.E. Y PROSEGUIR POR LA VÍA DE LAS LIBERALIZACIONES HEMOS ELEGIDO EL RIESGO

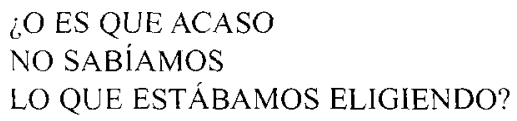

Un último procedimiento significativo en las poéticas del compromiso es la reescritura de obras previas en consonancia con las contingencias del presente. En la mayoría de los casos, los autores no pretenden impugnar el contenido de los textos originales, sino tan sólo adecuar su mensaje a unas coordenadas espaciotemporales concretas. Con todo, a veces estas modificaciones tienen, secundariamente, una función paródica. Los destellos irónicos y coloquiales contravienen la inquietud cosmológica que predominaba en la inmediata postguerra. Asimismo, el planteamiento de estos escritores sobre la difusión de su lírica es menos ingenuo que en los años cuarenta y cincuenta. Una vez asumida la escasa capacidad de conmoción política que posee la poesía, no hay ningún impedimento para explorar todos los medios expresivos a su alcance, incluyendo los mecanismos vanguardistas postergados durante el franquismo porque dificultaban la transitividad afectiva con el proletariado.

En este ámbito se sitúa («alimpsesto» (De lo realy su análisis, 1994), de Jesús Munárriz, que propone una relectura en clave satírica del célebre «Insomnio» que inauguraba Hijos de la ira (1944), de Dámaso Alonso. Sobre la plantilla de la poesía visual, Munárriz incorpora algunas alteraciones que señalan la distancia existente entre el original y la recreación contemporánea: tachaduras de frases, actualización de datos estadísticos y yuxtaposición de comentarios en letra bastardilla. Gracias a las citadas correcciones, el acento tremendista, que se centraba en el agonismo 
religioso en cuanto correlato de la situación del país, se traduce en un tono natural y hasta prosaico ${ }^{17}$. Esta glosa se articula sobre un referente directo, que engarza con los resortes del socialrealismo sin abdicar de los repuntes vanguardistas. Frente al desgarro de Dámaso Alonso, el poema de Munárriz muestra una mayor explicitud política. De hecho, reemplaza al interlocutor lejano (Dios) por un destinatario próximo (un diosecillo que cultiva bonsáis, en clara alusión a Felipe González, entonces Presidente del Gobierno). Por otra parte, el ensimismamiento de «Insomnio», donde el alma focalizaba la confidencia religiosa, se transforma ahora en un ejercicio solidario que recorre el camino hacia la colectividad. Al principio de su versión, Munárriz invoca a los «tres millones de parados» de la sociedad española y, en los dos versos finales, arremete contra los «inmensamente poderosos». Estos dos versos añaden una apostilla de la que carecía la pieza de Dámaso Alonso. No obstante, según muestra Prieto de Paula (1998: 253-254), Munárriz intenta compatibilizar en «Palimpsesto» el arrastre existencial de «Insomnio» con las notas culturales propias de su entorno histórico (Munárriz, 1994: 27):

ESPAÑA un paíscon tres millones de parados

MADRIO es traciutad de más de tmrmillón de catáveres

(según las últimas estadísticas)

A veces en la noche yo me revuelvo y me incorporo en

52 este nicho en el que hace 45 años que me pudro, aburro

y paso largas horas oyendo gemir al huracán, despero

o ladrar los perros, o fluir blandamente la luz de la luna, $o$

regoldar a los orondos,

Y paso largas horas gimiendo como el huracán, ladrando como un

perro enfurecido, fluyendo como la leche de la ubre caliente de una gran vaca amarilla cabreada, añorando justicia.

Y paso largas horas preguntándole a Dios, preguntándole al por qué se pudre lentamente mi alma esta gente tres millones de parados por qué se pudren más de unmillón de eadáveres en esta citudad de Matrie país llamado España,

por qué mil millones de eadáteres se pudren lentamente en el mundo tantos millones de parados, de parias

Dime, ¿ ¿qué huerto quiere abonar con nuestra podredumbre?

/le digo, diosecillo, pequeños bonsáis

$¿$ Temes que se te sequen los rosales-del día,

las tristes azucenas letales de tus noches?

¿Temes que mengüe levemente el poder

de los inmensamente poderosos?

${ }^{17}$ El aspecto visual de «Palimpsesto» conecta con la poesía concreta de José-Miguel Ullán (Frases, 1975, y Alarma, 1976) y de Fernando Millán (Mitogramas, 1978), quienes fundían una dimensión crítica con una plasmación icónica de la realidad que representaban. 
La revisión de textos previos también es un fenómeno habitual en los poetas de las promociones anteriores, sobre todo en algunos autores del medio siglo. Uno de los ejemplos más recientes es el de «Vallejo, hermano», de Félix Grande, recopilado en la antología 11M: Poemas contra el olvido (2004) ${ }^{18}$. Este poema entabla un diálogo con «Masa» (España, aparta de mí este cáliz, 1940), de César Vallejo $^{19}$. El homenaje de Grande reconstruye la estructura paralelística del discurso de Vallejo, si bien introduce cambios puntuales que inciden en las coyunturas políticas del presente («batalla» por «atentado», «combatiente» por «inocente»). A diferencia de los sujetos anónimos que, en la obra del peruano, se acercaban al soldado moribundo, Grande no vacila en ponerles rostro a los responsables de los conflictos internacionales. En contraste con los indeterminados «un hombre», «millones de individuos», «todos los hombres de la tierra», el autor nombra a Bin Laden, Bush \& Co, Sadam o Sharon. Sin embargo, la principal innovación de «Vallejo, hermano» consiste en el truncamiento del corolario de «Masa». En tanto que en el poema de Vallejo la unión de todos los hombres permitía la resurrección del cadáver, en el de Grande la meditación sobre las atrocidades internacionales desemboca en un desenlace amargo. En los versos que cierran la pieza, la víctima de las masacres increpa a sus verdugos y decide regresar a la muerte. Pese a este escorzo inesperado, los vínculos que ligan a esta composición con su modelo son más firmes que los que los separan. Por encima de su negatividad tópica, que renuncia a cualquier atisbo de esperanza, «Vallejo, hermano» entronca con el paisaje estético de la poesía social (Grande, en AA. VV., 2004: 78) ${ }^{20}$ :

Al fin del atentado

y muerto el inocente, vino hacia él Bin Laden

Is Este libro, dedicado a las víctimas de los atentados de Madrid, el 11 de marzo de 2004, coincide con el propósito del volumen $1 /$ de marzo. Poemas para el recuerdo (2004), compilado por Eduardo Jordá y José Mateos. Sin embargo, el poema de Grande no se concibe como una pieza de circunstancias, según se deduce de su mayor amplitud temática y de su precisa simetría con el texto de Vallejo.

${ }^{10}$ El conocido poema de César Vallejo, fechado el 10 de noviembre de 1937, decía: «Al fin de la batalla, / y muerto el combatiente, vino hacia él un hombre / y le dijo: ¡No mueras, te amo tanto! / Pero el cadáver jay! siguió muriendo. // Se le acercaron dos y repitiéronle: / No nos dejes! ;Valor! ;Vuclve a la vida! / Pero el cadáver ¡ay! siguió muriendo. // Acudieron a él veinte, cien, mil, quinientos mil, / clamando: ;Tanto amor y no poder nada contra la muerte! / Pero el cadáver ¡ay! siguió muriendo. // Le rodearon millones de individuos, / con un ruego común: /Quédate, hermano!/ Pero el cadáver jay! siguió muriendo. // Entonces, todos los hombres de la tierra / le rodearon; les vio el cadáver triste, emocionado; / incorporóse lentamente, / abrazó al primer hombre; echóse a andar...) (Vallejo, 1987: 259).

${ }^{20}$ Anteriormente, Blas de Otero había rendido tributo a Vallejo en «Vine hacia él (1952)» (Que trata de España, 1964). En esta composición, Otero se ceñía a los dictados de la poesía funeraria para elaborar un sentido homenaje que culminaba con la alusión intertextual a las obras más conocidas del autor peruano. Los versos finales del poema ya planteaban una ruptura con respecto al esperanzado 
y le dijo: « No mueras, te amo tanto!»

Pero el cadáver jay! siguió muriendo.

Al fin de la batalla

y muerto el inocente, vino hacia él Bush \& Co

y le dijo: « No mueras, te amo tanto!»

Pero el cadáver ¡ay! siguió muriendo.

Al fin de la tortura

y muerto el disidente, vino hacia él Sadam

y le dijo: « No mueras, te amo tanto!»

Pero el cadáver ¡ay! siguió muriendo.

Al fin del bombardeo

y muerto el niño palestino, vino hacia él Sharon

y le dijo: «¡No mueras, te amo tanto!»

Pero el cadáver ¡ay! siguió muriendo.

Al fin de la explosión del autobús

y muerto el niño de Israel, vino hacia él Arafat

y le dijo: « No mueras, te amo tanto!»

Pero el cadáver ¡ay! siguió muriendo.

Entonces, todos los seres piadosos de la tierra

rodearon al múltiple cadáver

con un ruego común: « $i$ Quédate, hermano!

¡No nos dejes! ¡Valor! ¡Vuelve a la vida!»

Los vio el cadáver triste, emocionado.

Intentó levantarse, abrazarlos, perdonar

y vivir. Abrió los ojos. Dijo:

«El peso de tanto asesinato no me deja moverme.

Perdónenme. Perdónenme».

Cerró los ojos y volvió a la muerte.

\section{Conclusión}

A lo largo de los últimos años, autores pertenecientes a distintas promociones concurren en la revitalización de unos moldes retóricos alejados del confesionalismo que potenció la tendencia social de la inmediata postguerra. A través de la recuperación del epigrama y la sátira, que asimilan las huellas desde la Antigüedad grecolatina hasta las derivaciones del Siglo de Oro, y a través del collage y la intertextualidad, que se cimientan en los precedentes de las vanguardias, la poesía española ha conseguido interiorizar desde una cierta distancia crítica los rasgos codificados en el realismo. Frente al excesivo mimetismo con que a menudo se ha

colofón de «Masa»: «Yo, / llorando, léi // Masa. / Entonces / todos los hombres de la tierra / le rodearon; pero // César Vallejo, ay! siguió muriendo» (Otero, 1985: 169). 
identificado a la lírica reciente, los nuevos escritores adaptan los patrones literarios preexistentes a los modos elocutivos contemporáneos, tanto en lo relativo a sus rasgos tonales (mordacidad, humorismo, agudeza final) como a sus temas (la burla de los trepadores, la denuncia de las convulsiones políticas o el escepticismo ante las hazañas militares). La emanación psíquica, la llaneza expresiva y la sonora musicalidad inciden en una atenta mirada a la historia y a la geografia costumbrista actual. En definitiva, los autores que desarrollan una poesía comprometida hacen suyo el anhelo formulado por Carlos Marzal en los versos de «Las buenas intenciones» ( $E l$ uiltimo de la fiesta): «Del lector solicito como único regalo / que esboce alguna vez una media sonrisa: / tan sólo busco cómplices que sepan de qué hablo». 


\section{BIBLIOGRAFÍA}

AA. VV., 11M: Poemas contra el olvido, Madrid, Bartleby, 2004.

BAgUé Quílez, Luis, La poesía de Victor Botas. Una relectura de los clásicos grecolatinos, Gijón, Llibros del Pexe, 2004.

Beltrán, Fernando, La semana fantástica, Madrid, Hiperión, 1999.

Benegas, Noni y Jesús MunárRIZ (eds.), Ellas tienen la palabra. Dos décadas de poesía española, Madrid, Hiperión, 1998 [1997].

Bonilla, Juan, Partes de guerra, Valencia, Pre-Textos, 1998 [1994].

Botas, Víctor, Poesía completa, Gijón, Llibros del Pexe, 1999.

CAno Ballesta, Juan (ed.), Poesia española reciente (1980-2000), Madrid, Cátedra, 2001.

CARNERO, Guillermo, Las armas abisinias. Estudios de literatura y arte del siglo XX, Barcelona, Anthropos, 1989.

CASADO, Miguel, «87 versus 78», Ínsula, 565 (1994), pp. 6-8.

CAstellet, José María (ed.), Nueve novísimos poetas españoles, Barcelona, Península, 2001 [1970].

CUENCA, Luis Alberto de, «La generación del lenguaje», Poesía, 5-6 (1979-1980), pp. 245-251.

- Los mundos y los días. Poesía 1972-1998, Madrid, Visor, 1999 [1998].

DíAZ de CASTRO, Francisco (ed.), La otra sentimentalidad. Estudio y antología, Sevilla, Fundación José Manuel Lara, 2003.

EgeA, Javier, Álvaro SAlvador y Luis García MonTERo, La otra sentimentalidad, Granada, Don Quijote, 1983.

García CASAdO, Pablo, Las afueras, Barcelona, DVD, 1997.

Garcia Martín, José Luis (ed.), Selección nacional. Última poesía española, Gijón, Llibros del Pexe, 1998 [1995].

GutiérRez CARBajo, Francisco, «La escritura en su punto de Luis Alberto de Cuenca», Cuadernos Hispanoamericanos, 537 (1995), pp. 130-134.

Hickson, Frances V., Roman Prayer Language. Livy and the Aeneid of Virgil, Stuttgart, Teubner, 1993.

IRAVEDRA, Araceli, «¿Hacia una poesía útil? Versiones del compromiso para el nuevo milenio», Ínsula, 671-672 (2002), pp. 2-8.

JordÁ, Eduardo y José MATEOS, ll de marzo. Poemas para el recuerdo, Valencia, Pre-Textos, 2004.

JUARISTI, Jon, «El pacto realista», Ínsula, 565 (1994), pp. 25-26.

- Poesía reunida (1985-1999), Madrid, Visor, 2000.

KeEFe Ugalde, Sharon, Conversaciones y poemas. La nueva poesía femenina española en castellano, Madrid, Siglo XXI, 1991.

LANZ, Juan José, «La joven poesía española. Notas para una periodización», Hispanic Review, 66 (1998), pp. 261-287. 
- Introducción al estudio de la generación poética española de 1968, Bilbao,

Universidad del País Vasco, 2000.

MaIner, José-Carlos, De postguerra (1951-1990), Barcelona, Crítica, 1994.

MARZAL, Carlos, Sin porqué ni adónde, Sevilla, Renacimiento, 2003.

MESA, Bruno, El laboratorio, Madrid, Visor, 2000.

MunÁRrIZ, Jesús, Otros labios me sueñan, Madrid, Hiperión, 1992.

- De lo real y su análisis, Madrid, Hiperión, 1994.

OTERO, Blas de, Que trata de España, Madrid, Visor, 1985 [1964].

Prieto de PAUla, Ángel L., Musa del 68. Claves de una generación poética, Madrid, Hiperión, 1998.

- «Sobre la poesía y el estatuto de la poesía en el año 2000», Diablotexto, 6 (2002), pp. 373-390.

R. DE LA FLOR, Fernando, «Neo-neo-clasicismos en la poesía española última», Los Cuadernos del Norte, 20 (1983), pp. 61-65.

Riechmann, Jorge, El día que dejé de leer El País, Madrid, Hiperión, 1997.

SÁNCHEZ TORRE, Leopoldo, «De lo real y sus retóricas: realismo y antipoesía en las nuevas poéticas del compromiso», Ínsula, 671-672 (2002), pp. 49-53.

SCARANO, Laura, «Travesías de la enunciación en las poéticas sociales españolas de postguerra», Cuadernos para Investigación de la Literatura Hispánica, 26 (2001), pp. 265-276.

SILES, Jaime, «Dinámica poética de la última década», Revista de Occidente, 112-113 (1991), pp. 149-169.

Valle.Jo, César, Poemas humanos. España, aparta de mi este cáliz, Madrid, Castalia, 1987 [1939 y 1940].

Valverde, Fernando, «Entrevista a Juan Carlos Rodríguez», El Paseo de los Tristes (versión digital del diario La Opinión de Granada), 2002.

VILlena, Luis Antonio de (ed.), La lógica de Orfeo, Madrid, Visor, 2003. 